\title{
HYDROGEN SULFIDE TOXICITY: TWO CASE REPORTS
}

\section{Munasinghe K.R.', Rascon M.A.', Diaze J.' \& Vadysinghe A.N. ${ }^{2}$}

'Office of the Medical Examiner and Forensic Laboratory, El Paso, Texas, USA, ${ }^{2}$ Department of Forensic Medicine, Faculty of Medical Sciences, University of Peradeniya, Sri Lanka

Corresponding author: Munasinghe K.R.

\begin{abstract}
Hydrogen sulfide $\left(\mathrm{H}_{2} \mathrm{~S}\right)$ toxicity is a known occupational/industrial hazard in organic decaying disposal, sulfur springs, natural gas well and coal pits. We report two deaths due to acute accidental hydrogen sulfide poisoning. Two males 40 and 36 years old were found dead in two different water treatment plants after spilling of sewage. Autopsy revealed greenish discoloration of skin and brain in one individual and pulmonary oedema in both. Toxicology revealed lethal levels of thiosulfate which is a metabolite of $\mathrm{H}_{2} \mathrm{~S}$. Death investigation concluded that both fatalities were due to toxicity of $\mathrm{H}_{2} \mathrm{~S}$ in an accidental manner. Toxicological investigations are important in cases where occupational hazards are suspected.
\end{abstract}

Keywords: Thiosulfate, $\mathrm{H}_{2} \mathrm{~S}$, Occupational hazard, Water treatment plant

All articles in Sri Lanka Journal of Forensic Medicine, Science \& Law are licensed under the terms of the Creative Commons Attribution-Non Commercial 4.0 International License 


\section{INTRODUCTION}

Hydrogen sulfide $\left(\mathrm{H}_{2} \mathrm{~S}\right)$ inhalation is not a rare presentation in routine forensic practice. Majority are accidental ${ }^{1-4}$ but rarely could be intentional. ${ }^{5-7} \mathrm{H}_{2} \mathrm{~S}$ is a colorless gas with the smell of rotten eggs, commonly generated by degrading of protein waste. It is also identified in sewers and is known commonly as "sewers gas". 8 It is flammable at ambient temperature and pressure is irritant and causes asphyxiation. ${ }^{9,10}$ We report two fatal cases of $\mathrm{H}_{2} \mathrm{~S}$ toxicity where toxicological analysis played a vital role in addressing important medico-legal issues.

\section{CASE REPORT}

\section{Case 01:}

A previously healthy 40-year-old male was working in a water treatment plant which was almost closed. His body was recovered submerged in spilled sewage hours later. The body was refrigerated till autopsy. Autopsy revealed early stage putrefaction including foul odour, swelling of body, marbling, peeling of epidermis and greenish color skin (Figure 01). Upper and lower airways showed a small amount of dark colored semisolid substance with retention of patency of air passage. Mild frothy fluid was noted on cut surface of lungs. Brain was greenish in color but otherwise normal. Other organs were normal macroscopically and microscopically except for early putrefactive changes. Femoral blood was positive for thiosulfate with a level of 10 $\mu \mathrm{g} / \mathrm{mL}$ by $\mathrm{GC} / \mathrm{MS}$.

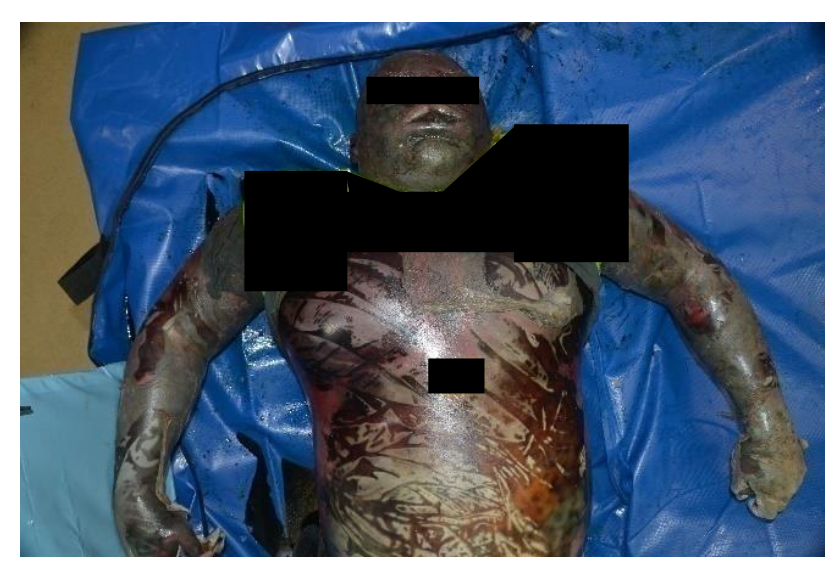

Fig. 01: Body showed early stage of putrefaction with green color hypostasis

\section{Case 02:}

A 34-year-old male working in a water treatment plant was trapped in a closed space due to sudden spillage of sewage. $\mathrm{He}$ died prior to initiating resuscitation.

He was an adult of average build. There was no evidence of putrefaction or greenish discoloration of skin (Figure 02). Respiratory passages were normal with no evidence of sewage within. Cut surface of the lungs showed mild frothy fluid. Mild atherosclerosis of the left coronary and mild fatty changes of the liver were noted. Other organs appeared normal macroscopically and microscopically. Toxicology revealed a thiosulfate level of $10 \mu \mathrm{g} / \mathrm{mL}$ by GC/MS.

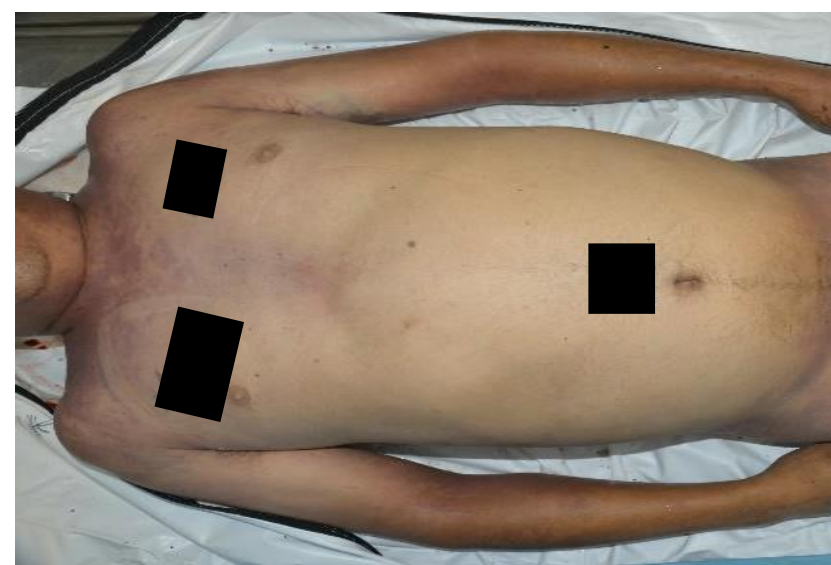

Fig. 02: No evidence of putrefaction and normal skin color 
The cause of death in both cases was confirmed as hydrogen sulfide gas toxicity. The manner of death was concluded as accidental.

\section{DISCUSSION}

$\mathrm{H}_{2} \mathrm{~S}$ toxicity is not commonly seen in forensic practice. $\mathrm{H}_{2} \mathrm{~S}$ is very unstable and rapidly converts to its main metabolite: thiosulfate which remains stable in the body. ${ }^{11-13}$ Therefore the level of thiosulfate is considered as a reliable marker of $\mathrm{H}_{2} \mathrm{~S}$ poisoning. ${ }^{3,14}$ However thiosulfate is naturally present in very low levels in blood and urine even in healthy individuals. ${ }^{15-17}$ In both cases, the blood levels of thiosulfate was above the toxic level $1^{1,2,5,18,19}$ and was sufficient to cause death.

It is well known that $\mathrm{H}_{2} \mathrm{~S}$ is produced naturally during putrefaction. ${ }^{20}$ Absorption of $\mathrm{H}_{2} \mathrm{~S}$ via the skin is also reported if body is exposed to high concentration of hydrogen sulfide. ${ }^{19}$ However there is a no huge influence on concentration of blood levels in our cases which showed very high level of toxicity. ${ }^{19}$ The mechanism of action of $\mathrm{H}_{2} \mathrm{~S}$ is almost similar to the action of cyanide where there is prevention of oxygen utilization at cellular level which is postulated as the mechanism of death in this case. $^{21}$

Low and moderate exposure to hydrogen sulfide mainly causes local tissue irritation with cyanosis, coma and rapid death in severe exposure. ${ }^{22-25}$ Minimal local reaction due to $\mathrm{H}_{2} \mathrm{~S}$ in these two individuals indicated that victims were exposed to high level of $\mathrm{H}_{2} \mathrm{~S}$ than lower level. Mild frothy fluid seen on cut sections of lungs in both the diseased indicates the possibility of asphyxia due to rapid exposure to high concentrations than local irritation which occurs in low and moderate exposure. ${ }^{26-28}$ Greenish discoloration of skin seen in one case is a recognized feature of $\mathrm{H}_{2} \mathrm{~S}$ poisoning. ${ }^{29-31}$ Similar discoloration was seen in the brain at autopsy of the same case which is consistent with previous fatal case reports. ${ }^{24}$
Findings at scene investigation and autopsy concluded that the manner was accidental in both instances. This assists the next of kin to claim insurance, compensation or any other benefits.

\section{CONCLUSION}

Toxicological investigation is vital where there is a suspicion of $\mathrm{H}_{2} \mathrm{~S}$ toxicity. Scene investigation with autopsy assisted in addressing possible issues which could arise in cases of $\mathrm{H}_{2} \mathrm{~S}$ toxicity especially in the working environment.

\section{Conflict of interest: none}

Funding: none

\section{REFERENCES}

1. Osbern LN, Crapo RO. Dung lung: a report of toxic exposure to liquid manure. Annals of internal medicine. 1981; 95(3): 312-4.

DOI: $10.7326 / 0003-4819-95-3-312$

2. Kimura K, Hasegawa M, Matsubara K, Maseda C, Kagawa M, Takahashi S, Tanabe KI. A fatal disaster case based on exposure to hydrogen sulfide-an estimation of the hydrogen sulfide concentration at the scene. Forensic science international. 1994; 66(2): 111-6.

3. Kage S, Takekawa K, Kurosaki K, Imamura T, Kudo K. The usefulness of thiosulfate as an indicator of hydrogen sulfide poisoning: three cases. International journal of legal medicine. 1997;110(4):220-2.

DOI:https://doi.org/10.1007/s0041400500 71

4. Chaturvedi AK, Smith DR, Canfield DV. A fatality caused by accidental production of hydrogen sulfide. Forensic science international. 2001; 123(2-3): 211-4.

DOI: https://doi.org/10.1016/S0379-0738 (01)00552-7

5. Winek C, Collom W, Wecht C. Death from hydrogen-sulphide fumes. The Lancet. 1968; 291(7551): 1096. 
6. Kobayashi K, Fukushima H. Suicidal poisoning due to hydrogen sulfide produced by mixing a liquid bath essence containing sulfur and a toilet bowl cleaner containing hydrochloric acid. Chudoku kenkyu: Chudoku Kenkyukai jun kikanshi= The Japanese journal of toxicology. 2008; 21(2):183-8.

7. Hatake K, Morimura Y, Kudo R, Ishitani A, Kusatani M, Fukudome A, Kasuda S. An autopsy case of death due to hydrogen sulfide poisoning. Hoigaku No Jissai To Kenkyu. 2007; 50: 171-4.

8. Schneider JS, Tobe EH, Mozley Jr PD, Barniskis L, Lidsky TI. Persistent cognitive and motor deficits following acute hydrogen sulphide poisoning. Occupational medicine. 1998; 48(4): 255-60.

DOI: https://doi.org/10.1093/occmed /48.4.255

9. NIOSH (National Institute of Occupational Safety and Health). 1977. Criteria for a Recommended Standard Occupational Exposure to Hydrogen Sulfide. DHEW (NIOSH) Publ No 77-158. Centers for Disease Control and Prevention Public Health Service, US Department of Health Education and Welfare. Washington, DC: US Government Printing Office.

10. Marshall T, Dorman D, Gardner D, Adeshina F. Provisional advisory levels (PALs) for hydrogen sulfide $\left(\mathrm{H}_{2} \mathrm{~S}\right)$. Inhalation toxicology. 2009; 21(sup3):5672.

DOI: https://www.tandfonline.com/doi/abs/ $10.3109 / 08958370903202812$.

11. Bartholomew TC, Powell GM, Dodgson KS, Curtis CG. Oxidation of sodium sulphide by rat liver, lungs and kidney. Biochemical pharmacology. 1980; 29(18): 2431-7.

DOI: https://doi.org/10.1016/0006-2952 (80) 90346-9

12. Beauchamp RO, Bus JS, Popp JA, Boreiko CJ, Andjelkovich DA, Leber P. A critical review of the literature on hydrogen sulfide toxicity. CRC Critical Reviews in Toxicology. 1984; 13(1):25-97.

DOI: https://doi.org/10.3109/10408448 409029321
13. Shih VE, Carney MM, Mandell R. A simple screening test for sulfite oxidase deficiency: detection of urinary thiosulfate by a modification of Sörbo's method. Clinica Chimica Acta; international journal of clinical chemistry. 1979; 95(1):143-5.

DOI: https://doi.org/10.1016/0009-8981 (79)90348-6

14. Kage S. Usefulness of thiosulfate as an indicator of hydrogen sulfide poisoning in forensic toxicological examination: a study with animal experiments. Japanese Journal of Forensic Toxicology.1992; 10: 223-7.

15. Kage S, Kudo K, Ikeda N. Determination of sulfide, thiosulfate and polysulfides in biological materials for diagnosis of sulfide poisoning. Japanese Journal of Forensic Toxicology. 1998; 16(3):179-89.

16. Kagedal B, Kallberg M, Martensson J, Sorbo B. Reversed-phase ion-pair liquid chromatographic procedure with electrochemical detection for the analysis of urinary thiosulphate. Journal of chromatography. 1983; 274:95-102.

DOI: $\quad$ https://doi.org/10.1016/S03784347(00)84412-6.

17. Kawanishi $\mathrm{T}$, Togawa $\mathrm{T}$, Ishigami $\mathrm{A}$, Tanabe S, Imanari T. Determination of thiosulfate in human urine and plasma by high performance liquid chromatography with a dual electrochemical detector. Bunseki Kagaku. 1984; 33(7):E295-300. DOI:https://doi.org/10.2116/ bunsekikagaku.33.7_E295

18. McAnalley BH, Lowry WT, Oliver RD, Garriott JC. Determination of inorganic sulfide and cyanide in blood using specific ion electrodes: application to the investigation of hydrogen sulfide and cyanide poisoning. Journal of Analytical Toxicology. 1979; 3(3): 111-4.

19. Maebashi K, Iwadate K, Sakai K, Takatsu A, Fukui K, Aoyagi M, Ochiai E, Nagai T. Toxicological analysis of 17 autopsy cases of hydrogen sulfide poisoning resulting from the inhalation of intentionally generated hydrogen sulfide gas. Forensic science international. 2011; 207(1-3): 91-5. DOI: https://doi.org/10.1016/ j.forsciint. 2010.09.008. 
20. Nagata T, Kage S, Kimura K, Kudo K, Noda M. Sulfide concentrations in postmortem mammalian tissues. Journal of Forensic Science. 1990; 35(3): 706-12.

DOI: $10.1520 / J F S 12876 J$

21. Smith, R.P. and Gosselin, R.E., 1979. Hydrogen sulfide poisoning. Journal of occupational medicine: official publication of the Industrial Medical Association; 21(2): 93-97.

22. National Institute for Occupational Safety and Health: Criteria for a recommended standard for occupational exposure to hydrogen sulfide. Cincinnati, OH (USA): National Institute for Occupational Safety and Health, 1977 [DHEW (NIOSH) Publ. No. 77-168].

23. Peters JW. Hydrogen sulfide poisoning in a hospital setting. Jama. 1981; 246(14): 155889.

DOI: 10.1001/jama.1981.03320140076038

24. Adelson L, Sunshine I. Fatal hydrogen sulfide intoxication. Report of three cases occurring in a sewer. Archives of Pathology \& Laboratory Medicine. 1966; 81(5): 375 80 .

25. Snyder JW, Safir EF, Summerville GP, Middleberg RA. Occupational fatality and persistent neurological sequelae after mass exposure to hydrogen sulfide. The American journal of emergency medicine. 1995; 13(2): 199-203.

DOI: https://doi.org/10.1016/0735-6757 (95)90094-2
26. Knight LD, Presnell SE. Death by sewer gas: case report of a double fatality and review of the literature. The American journal of forensic medicine and pathology. 2005; 26(2): 181-5.

DOI:10.1097/01.paf.0000163834.87968. 08

27. Gabbay DS, De Roos F, Perrone J. Twentyfoot fall averts fatality from massive hydrogen sulfide exposure. J Emerg Med 2001; 20: 141-4

28. Tanaka S, Fujimoto S, Tamagaki Y, Wakayama K, Shimada K, Yoshikawa J. Bronchial injury and pulmonary edema caused by hydrogen sulfide poisoning. The American journal of emergency medicine. 1999; 17(4): 427-9.

DOI: https://doi.org/10.1016/S0735-6757 (99)90102-X

29. Kage S, Ito S, Kishida T, Kudo K, Ikeda N. A fatal case of hydrogen sulfide poisoning in a geothermal power plant. Journal of Forensic Sciences. 1998; 43: 908-10.

30. Milby TH, Baselt RC. Hydrogen sulfide poisoning: clarification of some controversial issues. American journal of industrial medicine. 1999; 35(2): 192-5. DOI: https://doi.org/10.1002/(SICI) 10970274(199902)35:2\%3C192::AIDAJIM11\%3E3.0.CO;2-C

31. Ago M, Ago K, Ogata M. Two fatalities by hydrogen sulfide poisoning: variation of pathological and toxicological findings. Legal Medicine. 2008; 10(3): 148-52. DOI: https://doi.org/10.1016/j.legalmed. 2007.11.005. 